\section{Cultural Presupposition in Translation Strategy from English into Bahasa Indonesia on HBO Television Serial Game of Thrones Season 1

\author{
Adhitya Riska Yunita \\ Aris Munandar* \\ Linguistics Master Program, \\ Universitas Gadjah Mada \\ *arismunandar@ugm.ac.id
}

\title{
ABSTRAK
}

\begin{abstract}
This study aims to identify the cultural presupposition and how the translator applies translation strategies to convey cultural words into the target language. This study used qualitative descriptive for analyzing cultural presuppositions and translation strategies. The data used are utterances that contain cultural presuppositions found in the Game of Thrones television series season 1. This study shows that four types of sub-systems of cultural presupposition were found such as techno-economic, social, and linguistic system. The ideational system in the form of religion, ideology, values, ideas dominate the most compared to other sub-systems. Existential presupposition is the most frequent presupposition which appear followed with factive presupposition. Meanwhile, the translation strategy that frequently used is literal translation followed by borrowing and transposition translation strategy. This study emphasizes that some cultural words such as those belonging to the linguistic sub-system, in their translation to target language require an understanding of the cultural concept of the source language adapted to the cultural concept of target language.
\end{abstract}

Keywords: cultural presupposition; translation strategies; Game of Thrones

\section{INTRODUCTION}

A culture is unique because the existence of cultural words that may not be found in other languages (Padiernos 2018). Cultural word is formed by the cultural features such as certain language and cannot be translated literally (Newmark 1988). Newmark divided cultural word into five categories, which are 1) ecology (flora, fauna, weather, etc); 2) material cultural (foods, clothes, houses and cities, and transportation); 3) social culture (work and leisure); 4) organisation, tradition, activity, and concept; 5) gestures and habits. Then, Ping (1999) categorized cultural presupposition into four sub-systems, which are 1) Techno-economy system, 2) Social system, 3) Ideational system, and 4) Linguistics system.

The language belongs to culture. In line with Newmark (1988) which stated that culture is the way of living and manifestation of the society by using a language as a tool to express themselves. Lotman (in Bassnett-McGuire 2002: 23) mentioned that language is closely tied to culture "No language can exist unless it is deepened in the cultural context, whereas no culture does not have at its center, the natural language structure". Therefore, every group of people who have different languages can have different cultures. Language gives the chance to connect among people, situations, events, acts, beliefs, and feeling (Duranti 1997). So, an intermediary is needed to be able to communicate in one language with another. Translation can be an intermediary to bridge source and target language and culture between them. Torop (2002) mentioned that culture has its sign system or languages on the basis of which the member of the culture to communicate, so that possibility to understand a culture is to learn the language or the sign system of the culture.

Translation is the process of transferring messages from the source language into the target language (Newmark 1988; Hoed 2017). Pym (2010) viewed translation as the common communication activity between groups of cultural members. However, the barrier of translation is the heterogeny cultural transmission that is caused by the differentiation of cultural presupposition between the source

[160 - 169] Yunita, Adhitya Riska \& Aris Munandar. 2020. Cultural Presupposition in Translation Strategy from English into Bahasa Indonesia on HBO Television Serial Game of Thrones Season 1. Deskripsi Bahasa Vol. 3(2). 2020, pp. 160-169. https://jurnal.ugm.ac.id/v3/db 
language and target language (Wang 2020). Culture produces unequal presuppositions because it is socially and culturally bound so that it can cause communication problems even though there is mastery of proper linguistic competence. The concept of presupposition is related to "shared knowledge" between the writer and the reader (Abualadas 2015) which can be connected to the process of inferencing by the reader (Sanchez 2009).

Presupposition relates to the assumptions made by the speaker before uttering an utterance (Yule 1996). Ehrman (1993) mentioned that presupposition relates to the linguistic and the extra-linguistic context which the readers or hearers could make an inference from that linguistic expression. Presuppositions are divided into six types, namely existential presupposition, factive presupposition, non-factive presupposition, lexical presupposition, structural presupposition, and counterfactual presupposition (see table 1).

Tabel 1. Type of presuppositions

\begin{tabular}{lll}
\hline Jenis presuposisi & Contoh & Presuposisi \\
\hline Eksistensial & "The X" & > X exist \\
Faktif & "I'm glad that you like it" & > You liked it \\
Non-faktif & "She dreamed to be millionaire" & > She was no millionaire \\
Lexical & "He stopped smoking" & > He used to smoke \\
Structural & "Who took her?" & > Someone took her \\
Counterfactual & "If I were not your king..." & > l am your king \\
\hline
\end{tabular}

Cultural presupposition includes the assumptions that underlie cultural values, beliefs, customs, ideas, and words (Fawcett 1997) which also should be owned by the reader of the target language. Cultural presupposition can lead to misunderstanding of the source language because there is an interrelation between presupposition and text understanding. Ping stated that presupposition can be passed down culturally and needs to be paid attention to in the translation. In translation, the cultural presupposition is the cultural knowledge of the source text that the target reader is assumed to have by the translator (Chen 2008). Errors in the translation lead to misunderstanding and misinterpretation between people who do not share the same culture (Padiernos 2018), damage the message, and produce communication disorders between the source language author and the reader of the target language (Ping 1999). This gap is the problem for the translator in translating.

According to Baker (1992), a translator must have knowledge of the language and culture of the target audience. So that, a simple literal translation would not satisfy the target language reader who has lack knowledge about the culture background (Samimi and Abbasi 2014). In order to overcome those problems, translators use strategies of translating SL to TL. Translation strategies (Vinay and Darbelnet 2000) can be adapted to translate the cultural items. Vinay and Dalbernet (2000) proposed 7 strategies which divided into two categories; directed translation and indirect translation. Directed translation includes borrowing, calque, and literal translation. Borrowing is the translation strategy that directly borrowed the source language words into the target language without translating it. Calque is the translation strategy which adapted the structure of the source language and translating it word by word in the target language. Literal translation or word-for-word translation is the translation strategy that translated directly SL grammatically into the target language. Meanwhile, indirect translation involves transposition, modulation, equivalence, and adaptation. Transposition is the strategy used by changing the word class or word combination without changing the message of $\mathrm{SL}$. Modulation is the translation strategy that changes the point of view of SL. Equivalence is the translation strategy that transfers the message of SL to the closest equivalence available in the TL. Adaptation is the translation strategy by adapting suitable TL words or phrases or expressions when there is no suitable or appropriate culturally SL word in the target language. 


\section{METHODOLOGY}

This study used descriptive qualitative methods. Moleong (2000) stated that qualitative research is the research procedure that produces descriptive data in the form of words or speech from people and observable behavior. Creswell (2009) added that the use of qualitative description methods is to identify clauses, sentences, and translated them into words. Thus, the researcher applied this method for identifying and describing cultural presuppositions and translation strategies applied in the Game of Thrones season 1.

The data source of this research is the HBO television series Game of Thrones season 1 which has been officially translated into Bahasa Indonesia. The researcher chose Game of Thrones because it was the most popular television series and had a historical fantasy background in which the cultural presuppositions can be found and analyzed. This study focused on 88 speech in conversation that contain cultural presuppositions and translation strategy used in translating speech contain cultural presuppositions.

\section{RESULTS AND DISCUSSION}

\section{Cultural Presupposition}

This study applied presupposition theory by Yule (1996) which divides presuppositions into six categories which are existential, factive, structural, lexical, non-factive, and counterfactual. The results are presented in the table 2 below.

Table 2. Result of types of presupposition

\begin{tabular}{llcc}
\hline No. & Presupposition tupes & Jumlah & Persentase \\
\hline 1. & Existential & 46 & $52 \%$ \\
2. & Factive & 15 & $17 \%$ \\
3. & Structural & 11 & $13 \%$ \\
\hline 4. & Lexical & 7 & $8 \%$ \\
5. & Non-factive & 4 & $5 \%$ \\
6. & Counterfactual & 5 & $5 \%$ \\
& $\quad$ Jumlah & 88 & $100 \%$ \\
\hline
\end{tabular}

Table 2 shows that of the 88 utterances containing presupposition, there are 46 utterances categorized as existential presuppositions that dominate the conversation. Speakers in Game of Thrones use some linguistic forms (definite and possessive structure) to represent an entity. Furthermore, factive presupposition follows with $17 \%$ used to state the fact or factiveness through some verbs. Structural presupposition (13\%) states that sentences are assumed to be true through certain sentence structures. Then, lexical presupposition (8\%), counterfactual (5\%), and non-factive presuppositions with a percentage of $5 \%$.

Next, the study about words that contain cultural presuppositions are categorized into cultural systems concept by Ping (1999), namely 1) techno-economic system, 2) social system, 3) ideational system, and 4) linguistic system. The result of the cultural presupposition which categorized into Ping's concept can be seen in Table 3 below.

Table 3. Result of cultural sub-systems

\begin{tabular}{llcc}
\hline No. & Cultural sub-systems & Amount & Percentage \\
\hline 1. & Techno-economic system & 27 & $31 \%$ \\
\hline
\end{tabular}




\begin{tabular}{rrcc}
\hline 2. & Social system & 29 & $33 \%$ \\
\hline 3. & Ideational system & 30 & $34 \%$ \\
\hline 4. & Linguistics system & 2 & $2 \%$ \\
& Total amount & 88 & $100 \%$ \\
\hline
\end{tabular}

Table 3 above shows that the ideational cultural system concept is the most frequent cultural system in Game of Thrones. The ideational system shows that speakers use linguistic forms through presuppositions to state the existence of culture in the aspects of religion, ideology, religion, values, and folklore. Furthermore, the social systems (33\%) and techno-economic (31\%). In a technoeconomic cultural system, there are aspects of ecological (fauna) and material culture, while in a social system there are social class, type of work, politics and law, and activity. A Linguistic system is a cultural word that has different meanings from its semantic meaning. In this study, it was found that two data (2\%) were categorized in the linguistic system.

\section{Cultural Translation Strategy}

Translation strategy by Vinay and Darbelnet (2000) applied to identify the translation strategy used in translating cultural words. There are seven translation strategies by Vinay and Darbelnet, which are borrowing, calque, transposition, modulation, equivalence, adaptation, dan literal translation. These are the result of the translation strategy arranged in Table 4.

Table 4. Result of translation strategies

\begin{tabular}{llcc}
\hline No. & Translation Strategies & Amount & Percentage \\
\hline 1. & Literal translation & 23 & $26 \%$ \\
2. & Borrowing & 20 & $23 \%$ \\
3. & Transposition & 13 & $15 \%$ \\
4. & Equivalence & 13 & $15 \%$ \\
5. & Adaptation & 12 & $14 \%$ \\
6. & Modulation & 6 & $7 \%$ \\
7. & Calque & 1 & $1 \%$ \\
\hline & Total amount & 88 & $100 \%$ \\
\hline
\end{tabular}

Table 4 shows that literal translation strategy is the most commonly used translation strategy. Then, the use of translation strategies is then followed by the borrowing translation strategy with 20 data. Furthermore, the transposition and equivalence strategy (15\%), adaptation (14\%), modulation (7\%), and the least is calque (1\%).

\section{Cultural presupposition and Translation Strategy}

\section{a. Techno-economic System}

Techno-economic system is the cultural concept system proposed by Ping (1999) which involves ecology (flora, fauna, weather, etc.), means of production, exchange, distribution of goods, craft, technology, science, and artifacts (1999). In the techno-economic, the researcher found ecology (fauna) 4 data and material culture dominating with 23 data which consist of name of foods, craft, kingdoms, and architects. Meanwhile, the existential presupposition is the presupposition that most often appear in this system. Translation strategies of borrowing which frequently used by the translator and then followed by literal translation and adaptation. 
1) Existential presupposition

Existential presupposition is the presupposition which assume the existence of an entity in an utterance. Existential presupposition is triggered by the definite description includes noun phrase with article "the" and proper nouns (El-Gamal 2001), possessive form "my, your, their, our" and aphostrope.

[00:16:30, $200-->00: 16: 34,560]$

(1) a. SL: The direwolf is the sigil of your House.

b. TL: Direwolf adalah lambang gaib dari House Stark.

>> Direwolf is exist.

The context of the story above is when the group of Stark family found a carcass which was surrounded by the cubs. Lord Stark as the leader recognizes that the animal is called a direwolf and forbids his son, Brandon Stark, to keep the animal as a pet. Then, Jon Snow mediates differences arguments between Lord Stark and Brandon about raising the animal or leaving it in the forest.

Example in (1)a triggers an existential presupposition which is indicated by the definite form "the" in SL. The existential presupposition in the sentence above states the existence of an entity called "direwolf". The noun phrase "The direwolf" itself is translated into "direwolf" using borrowing translation strategy. Borrowing strategy is used because there is no equivalent word in the target language. The direwolf is a wolf-like animal that does not appear in the culture of the target language, so that there is no suitable equivalent for the word. The direwolf is an animal that only appears in snowy areas such as described in Winterfell. In the real world, the direwolf lives in North and South America. The direwolf is an ancient wolf with a larger size and more aggressive than wolves in general. The direwolf is included in the ecology (fauna) category which is classified under the sub-system of cultural presupposition of the techno-economic system.

[00:21:35, $200-->00: 21: 37,560]$

(2) a. SL: We've brought up eight barrels of ale from the cellar.

b. TL: Kita punya 8 tong minuman keras dibawa dari ruang tanah.

>> There is a cellar.

The conversation in 2(a) has context when the Stark family, the leader clan of the Winterfell kingdom, guest The King and Queen of the King's Landing in their kingdom. The servants of Winterfell were preparing a dish that the royal family would normally eat. In sentence 2 there is an existential presupposition triggered by the definite form of "the". The presupposition states a cellar in the royal building of Winterfell. The word "the cellar" itself is translated into 'ruang tanah' with a literal translation. Cellar is a room below ground level in a house that is used to store wine or coal found in the interior of western houses. In the culture of the target language, Indonesia, there is no interior structure such as cellar due to cultural differences. Cellar is included in the material culture category which is classified in the techno-economic sub-system.

\section{b. Ideational System}

Ideational system is a system which involves cosmology, religion, magic and witchcraft, folklore, values, artistic creations, cognitive and thinking patterns, and ideology (Ping 1999). In this research, the researcher found that organization dominates the system, then followed by ideology and values with each 5 data, religion and idea with each 4 data, and the less are procedures, folklore, and artistic creation. In the meantime, existential presupposition commonly appears in the utterance with 12 data and followed by factive presupposition with 8 data. Then, the next position is lexical, structure, counterfactual and non-factive presupposition. The translation strategy which commonly used in ideational system is literal translation. Then, followed by borrowing, transposition, equivalence strategy, adaptation, modulation, and calque. Here are the examples of data taken with the most data found in this system and represents an example of the presupposition contained in this study. 
1) Existential Presupposition

[00:10:56,480 --> 00:11:01,880]

(3) a. SL: The law is law, my Lady.

>> There exist law.

b. TL: Hukum harus ditegakkan, Yang Mulia.

'The law needs to be enforced, my Lady.'

Example 3 (a) above triggers an existential presupposition with the definite article the which presuppose that law is exist or there is a law that regulates it. The sentence "The law is law" itself has an implicit meaning which states that "you have no point in opposing and must obey the existing rules or if you do not, you have to face the consequences". The sentence above is translated into the target language with a modulation translation strategy that is adapted to the correct expression in the target language. the sentence "The law is law" is included in the category as ideology and classified into ideational system.

\section{2) Lexical Presupposition}

Lexical presupposition assumes that there are other meanings asserted when the speaker makes utterances. Lexical presupposition can be triggered by the use of implicative verbs (manage, forget, happened to, etc.), change of state verbs (stop, continue, begin, start finish, etc.), iteratives (again, repeat, return, for the nth time). The following is an example found in utterances containing lexical presupposition.

[00:35:42,680 --> 00:35:46,400]

(4) a. SL: I have prayed to the Seven for more than a month.

>> Aku berdoa lebih dari sekali pada 7 Dewa.

b. TL: Aku telah berdoa pada 7 Dewa lebih dari sebulan.

'I have prayed to the Seven Gods more than a month.'

Example $4(a)$ triggers the emergence of a lexical presupposition marked by the iterative word "for more than a month", which means that prayer has been done many times or more than a month. The translation above uses the equivalent translation. Translation of "the Seven" translated to "Seven Gods".

The word "the Seven" is a culture word that is categorized into religion and classified under the ideational system. In the target language culture, Gods can be translated into Allah (Islam), Tuhan or Jesus (Christian), and Dewa (Buddhist, Hindu). In the religious culture in Game of Thrones, there are three main beliefs, namely The Old Gods, Faith of The Seven, and The Drowned God. The Old Gods 'Dewa Lama' is an animistic belief in which followers worship old trees, water, rocks, wind, and animals. Faith of The Seven 'New Gods or Seven Gods' is a belief that worships the Seven Gods which the Father represents judgment, Mother represents motherhood and fertility, Warrior represents power, Maiden represents purity, Smith as the god of craft and labor, Crone as the god of wisdom and Stranger represents death and the unknown. Furthermore, The Drowned God is a belief that was created based on Norse mythology. This belief believes that killing, looting, robbing is an honorable act because taking something by force from another person.

\section{3) Factive Presupposition}

Factive presuppositions are assumptions that are considered as a fact because they are triggered by words that indicate the truth. Factive words such as know, see, realize, regret, be aware, be glad, be sorry, odd. Factive presuppositions can also be triggered by the emergence of the temporal clause when, while, after, since. Here are examples of utterances that contain factive presuppositions.

[00:14:03, $240-->00: 14: 06,680]$

(5) a. SL: You know our words, Winter is coming. 
Adhitya Riska Yunita \& Aris Munandar

'Kau tau slogan kita. Winter is coming.'

>> slogan kita 'winter is coming'

b. TL: Kau harus tepati janji. Musim dingin akan datang.

'You have to keep promises. Winter is coming.'

>> your promises.

The utterance 5(a) has context when Lord Stark is advising his daughter, Arya Stark, that winter is coming with a longer duration and during that season any hardships can occur, so that Stark's family have to protect each other. In utterance 5 (a) contains factive presupposition which is triggered by the word "know" which presupposes that Arya knows very well the slogan of his family, namely winter is coming. Meanwhile, in the target language $5(\mathrm{~b})$ is translated with modulation translation strategy where the translation is done by changing the point of view into harus tepati janji 'must keep promises' where the utterance does not trigger factive presuppositions.

\section{c. Social System}

Social system includes social classes, kinship system, politics and law, education, sports and entertainment, customs, general history (Ping 1999). In the social system, there are many kinds of works that show social class and dominate the data. Then, followed by politics and law and activity. The presupposition which mostly appears is existential ( 14 data), factive ( 5 data), structural ( 5 data), counterfactual, lexical, and the least is non-factive. Subsequently, the translation strategy which used frequently is literal translation ( 8 data) and followed by equivalence strategy ( 7 data), transposition ( 6 data), borrowing (5 data), modulation (2 data), and adaptation (1 data). In the example of social system, the example of counterfactual presupposition, structural presupposition, and non-factive presupposition will be displayed as they have not been mentioned in the examples.

\section{1) Counterfactual Presupposition}

Counterfactual presupposition assumes that the utterance uttered is contrary to facts. Counterfactual presupposition is triggered by the use of if-clause sentence which states a supposition that does not occur. The sentence below is an example of a counterfactual presupposition in a social system (social class, law and politics).

[00:18:52,280 --> 00:18:54,800]

(6) a. SL: If he told the King... both our heads would be skewered on the city gates by now.

> dia tidak mengatakan kepada Raja, sehingga kepala kita tidak dipasak di atas pintu gerbang sekarang.

b. TL: Jika dia mengadu pada Raja kepala kita berdua akan digantung di pintu gerbang kota saat ini.

'If he snitches to the King, both our heads would be hanged at the city gates at this time.' > dia tidak mengadu ke Raja, jadi kepala kita tidak digantung di gerbang kota sekarang.

Utterance 6(a) presuppose that "our head wouldn't be spiked because he did not tell to the King". Meanwhile, in the example point (b) presuppose that "our head would not be hanged because he did not tell the king". The translation of the sentence above uses modulation strategy. In the sentence above, SL to TL translation provide different perception to the target language readers. In the SL, the word "told" has literal meaning as 'mengatakan', but in the sentence above, the word "told" translated into snitches which has literal meaning as 'mengadu'. In the target language, the word 'mengatakan' and 'mengadu' has different meaning. The word mengatakan has meaning as "informing something", therefore the word mengadu has negative meaning which is "telling something by making other people looked worse".

The other also has to be happened in the word "skewered" which translated to TL as 'digantung'. In the culture that occurs the serial television Game of Thrones, the punishment of "hanging" is different from "skewering". The punishment of "hanging" is a punishment given by the king by hanging the victim using a rope and then there is an executioner who is ready to execute. Meanwhile, the 
"skewering" punishment is a continuation of the execution sentence in which the limbs of the heads of the traitors are stabbed with iron and then their head would be put in the city gates to be displayed to the residents.

\section{2) Structural Presupposition}

Structural presupposition is the presupposition which triggered from certain sentence structures and assumed to be true. Sentence structure which treated as true information include wh-construction, even construction, adverbial clauses, it-cleft, and given construction (Manu 2020). The example of structural presupposition mentioned below.

[00:37:04,680 --> 00:37:17,680]

(7) a. SL: Making us take our vows... while they sneak off for a little sally on the side?

\section{b. TL: Memaksa kita bekerja saat mereka diam-diam pergi bercinta?}

The context of the utterance above is when Sam complains that several guards are sneaking out on other activities and neglecting their duties for guiding the gate. The utterance above contain a structural presupposition with a complete sentence construction "Why are they making us take our vows while they sneak off for a little sally?" which presuppose that some people secretly go out to make love. The strategy of translating "a little sally on the side" into the target language uses an adaptation strategy. The on the side expression is a common form of expression in British English which states "marital-affairs". In the $T L$, the expression sentence "a little sally on the side" is not available, so the translator can adapt with appropriate word for the expression through the context of the conversation. The sentence "a little sally on the side" is a form of activity category that can be categorized into social sub-systems.

\section{3) Non-factive Presupposition}

Non-factive presupposition is the presupposition which assume not to be true. Non-factive presupposition is triggered by the use of the words such as dream, imagine, pretend, sound like, should have/ have never. The following is an example of utterance which contain non-factive presupposition.

[00:39:49,080 --> 00:39:52,160]

(8) a. SL: You should have known she was a whore.

>> faktanya, kamu tidak tahu bahwa ia adalah PSK

b. TL: Seharusnya kau tahu dia seorang PSK.

'Should have you know she was a prostitute.'

Utterance 8(a) and (b) are indicated as non-factive presupposition which presuppose that in fact, the speaker does not know that she was a whore. The translation strategy applied in the utterance above is equivalence strategy. The word "whore" is translated as 'PSK' (Pekerja Seks Komersial) which is the euphemism form of 'pelacur'. Recently, many experts and practitioners change using the tem pelacur into PSK (Koentjoro and Sugihastuti 2012). Koentjoro \& Sugiharti (2012) also states that the term of PSK itself is a gender biased term, more specifically connotatively and denotatively.

\section{d. Linguistic System}

Linguistic system is the sub-system which arranged from phonology, morphology, syntax, semantics, and pragmatics (Ping 1999). Linguistic system is the sub-subsystem which cultural presupposition might be traced by semantics or structure of a language. Meanwhile, deep-rooted cultural presupposition which held cultural values can lead translator into misrepresent the message (Ping 1999).

[00:20:55,920 --> 00:20:57,800]

(9) a. SL: The raven brought more news.

>> The raven exists. 'Ada burung gagak' 
Adhitya Riska Yunita \& Aris Munandar

b. TL: Ada berita buruk yang lain

'There was another bad news.'

In the example above, the noun phrase "the raven" is translated into 'berita buruk' or bad news. In the utterance 9(a) above gives assumption that "there is a raven" which triggered by definite article "the" in $S L$, while in the TL gives assumption that "there is bad news." This is because the translator uses adaptation strategy. The translator translated "the raven" into 'berita buruk' or bad news. This is because the cultural background raised in the Game of Thrones is European history where the birds such as doves or crows are used as intermediaries to deliver news. The birds can travel hundreds of miles in a day for carrying letters pinned to their feet. In literature and myths, the raven is represented as a symbol that bring death and calamity. This culture of myths is carried over into the translation.

[00:45:56,200 --> 00:45:57,960]

(10) a. SL: Pardon, my Lord, my Lady. A rider in the night from your sister.

$>$ A rider exist

b. TL: Permisi, Yang Mulia. Ada kabar malam ini dari saudara perempuanmu.

>> There is news in the night

In the example 10(a), the phrase "A rider in the night" is translated into 'kabar malam'. The utterance in the sentence above used adaptation strategy which translate the situation referred in SL into TL with the equivalence word. The translation above translates "A rider" to 'kabar'. The word "Rider", if it is translated literally becomes "a horse rider" because in the background of the Game of Thrones is taken in a century in which horses were used as a means of transportation. The translation into 'kabar' can also be caused by the confidentiality of a message so that the recipient of the message so that the recipient of the message must be the right person in receiving. Hence, delivering message using crows was replaced by horse rider.

\section{CONCLUSION}

Presupposition in Bahasa Indonesia can be triggered as the same trigger as in English. This is because the language structure of Bahasa Indonesia and English have in common, so that literal translation can be used as translation strategy to trigger presuppositions. Context in the SL is influential in translating cultural presupposition. Some culture-bound words such as the raven translated as 'bad news', so that cannot be translated lexically. Lexical translation will to a misleading in interpreting the meaning into TL. As a result, translators have to understand the cultural background in SL and TL in order to be able to convey the meaning back in accordance with the SL. Borrowing strategy is the strategy that most used in the techno-economic sub-system because some cultural words have no equivalent in TL. Adaptation strategy is used to translate cultural words that do not have an appropriate equivalent in the TL. On the other hand, Equivalence strategy is the most used strategy in the social sub-system because some cultural words in SL have an equivalent meaning in the TL.

\section{REFERENCES}

Abualadas, Othman Ahmad Ali. 2015. "A Linguistically-Oriented Approach to Literary Translation: A Comparative Pragmatic Study of Three Arabic Renditions of the English Novel 'Wuthering Heights."' Dissertation, United Kingdom: University of Leeds. https://etheses.whiterose.ac.uk/9424/.

Baker, Mona. 1992. In Other Words a Coursebook on Translation. London: Routledge.

Bassnett-McGuire, Susan. 2002. Translation Studies. London: Routledge.

Chen, Shuming. 2008. "Cultural Presupposition and Decision-Making in the Functional Approach to Translation." Journal of Humanities and Social Sciences 4 (1): 83-89. http://journal.dyu.edu.tw/dyujo/document/hssjournal/ho4-1-83-89.pdf.

Duranti, Alessandro. 1997. Linguistic Anthropology. https://doi.org/10.1017/CBO9780511810190. 
Ehrman, James. 1993. "Pragmatics and Translation: The Problem of Presupposition." TTR: Traduction, Terminologie, Rédaction 6 (1). Association canadienne de traductologie: 149-70. doi:10.7202/037142ar.

El-Gamal, Ayman. 2001. "Presupposition, Perceptional Relativity and Translation Theory." Alicante Journal of English Studies / Revista Alicantina de Estudios Ingleses, no. 14 (November): 37-62. doi:10.14198/raei.2001.14.03.

Fawcett, Peter. 1997. Translation and Language. Manchester: St. Jerome.

Hoed, Benny H. 2017. "Penerjemah, Penerjemahan, Terjemahan, dan Dinamika Budaya: Menatap Peran Penerjemahan pada Masa Lalu di Nusantara." Masyarakat Indonesia 37 (1): 57-80. doi:10.14203/jmi.v37i1.601.

Koentjoro, Koentjoro, and Sugihastuti Sugihastuti. 2012. "Pelacur, Wanita Tuna Susila, Pekerja Seks, dan 'Apa Lagi': Stigmatisasi Istilah." Humaniora 11 (2): 30-33. doi:10.22146/jh.66o.

Manu, James Gyimah. 2020. "Presupposition in Ghanaian and British Newspaper Editorials." Ghana Journal of Linguistics 9 (1): 18-45. doi:10.4314/gjl.vgi1.2.

Moleong, Lexy J. 2000. Metodologi penelitian kualitatif. Bandung: PT Remaja Rosdakarya.

Newmark, Peter. 1988. A Textbook of Translation. New York: Prentice Hall.

Padiernos, Maria Olive Gay. 2018. "Cultural Presupposition and Accommodation," November. The Journal of Studies in Language, 457-73. doi:10.18627/jslg.34·3.201811.457.

Ping, Ke. 1999. "Cultural Presuppositions and Misreadings." Meta : Journal Des Traducteurs / Meta: Translators' Journal 44 (1). Les Presses de l'Université de Montréal: 133-43. doi:10.7202/003296ar.

Pym, Anthony. 2010. Exploring Translation Theories. London; New York: Routledge.

Samimi, Muhammad Reza, and Pyeaam Abbasi. 2014. "Cultural Presuppositions in Translation from Persian into English: A Case Study of Two Persian Novels: The Blind Owl and The School Principal." The Criterion An International Journal in English 5 (II): 467-80. https://www.thecriterion.com/V5/n2/Samimi.pdf.

Sanchez, Maria T. 2009. The Problems of Literary Translation: A Study of the Theory and Practice of Translation from English into Spanish. Oxford; New York: P. Lang.

Torop, Peeter. 2002. "Translation as Translating as Culture." Sign Systems Studies 30 (2): 593-605. doi:10.12697/SSS.2002.30.2.14.

Vinay, Jean-Paul, and Jean Darbelnet. 2000. "A Methodology for Translation." In The Translation Studies Reader, edited by Lawrence Venuti, 84-93. London: Routledge.

Wang, Ningning. 2020. "A Comparative Study of Folk Culture Translation from the Perspective of Cultural Presupposition-Taking Four English Versions of Biancheng as an Example." Open Access Library Journal 7 (5). Scientific Research Publishing: 1-9. doi:10.4236/oalib.1106397.

Yule, George. 1996. Pragmatics. Oxford: Oxford University Press. 